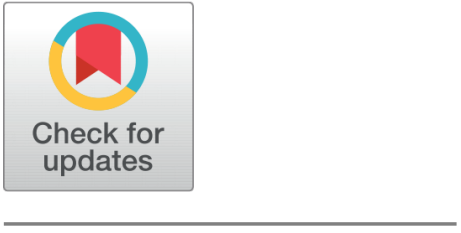

open access

Received: 28.05.2021

Accepted: 02.09.2021

Published: 09.11.2021

Citation: Casillano NFB, Azura AA, Abenis EB, Madeja JB (2021)

Comparative Historical Trends of Faculty Performance in Instruction, Research and Extension in a Philippine State University. Indian Journal of Science and Technology 14(37): 2865-2870. https://doi.org/ 10.17485/IJST/v14i37.946

* Corresponding author.

nfcasillano@gmail.com

Funding: None

Competing Interests: None

Copyright: (c) 2021 Casillano et al. This is an open access article distributed under the terms of the Creative Commons Attribution License, which permits unrestricted use, distribution, and reproduction in any medium, provided the original author and source are credited.

Published By Indian Society for Education and Environment (iSee)

ISSN

Print: 0974-6846

Electronic: 0974-5645

\section{Comparative Historical Trends of Faculty Performance in Instruction, Research and Extension in a Philippine State University}

\author{
Niel Francis B Casillano ${ }^{1 *}$, Arceli A Azura ${ }^{1}$, Erlick B Abenis ${ }^{1}$, Jovito B Madeja ${ }^{1}$ \\ 1 Eastern Samar State University, Philippines
}

\section{Abstract}

Objectives: This research focused on the determining the difference of faculty performance in instruction, research and extension in the last 3 years. Methods: The researcher used mean, variance percentage, ANOVA and Kruskal-Wallis test to determine the difference of faculty performance from 2017-2018. Findings: The analyses revealed that there were positive variance percentages of faculty performance in instruction (+2.47\%) and extension $(+14.28 \%)$ while a negative variance percentage was recorded for research (-4.62\%) from 2017-2018. Furthermore, a negative variance percentage for instruction $(-0.43 \%)$, research $(-12.9 \%)$ and extension $(-25 \%)$ was recorded from 2018-2019. The same analysis also revealed that there is no significant difference of the faculty performance in instruction ( $p$-value $=.8704)$, research $(p$-value $=0.48486)$ and extension ( $p$-value $=0.14412$ ) from 2017-2019. The negative variance percentage is indicative of a waning productivity which can be attributed to many factors such as lack of time in the conduct of extension and research, lack of funding support and lack of community participation. Novelty: The result of the study can be utilized as inputs the creation of policies that are geared towards the improvement of faculty performance.

Keywords: trend; faculty performance; instruction; research; extension

\section{Introduction}

Human resources are the most precious asset of every institution. They define an organization's efficiency, effectiveness, and overall service quality. Human resources are the key for the acquisition, utilization, and development of the organization's potentially exhaustible financial, material, technological, and market resources ${ }^{(1)}$. One of the most important human resource in every country are educators. Educators play a critical part in a country's educational system's achievement of its aims and objectives. In a school, the teacher is one of the most essential component ${ }^{(2)}$. A university faculty members' performance and success are determined by how they perceive and know the fundamental principles of teaching, research, and service in such a way that they make the best use of available resources. Faculty members are also expected to make significant contributions to their students' academic development and learning ${ }^{(3)}$. In any institution of higher education, evaluating faculty effectiveness is critical. Assessing 
teaching performance allows you to assess the institution's instructional quality and help students learn more effectively ${ }^{(4)}$. The idea that teacher performance evaluation can be a crucial factor in enhancing the focus on teaching quality and continual professional development for teachers is gaining traction among education stakeholders. This idea aligns with the emerging knowledge that teaching quality has an impact on student learning outcomes ${ }^{(5)}$. In the field of education, comparative analysis is a great help in attaining educational goals through comparisons of assessment of the different aspects of education in certain periods, including the performance of teachers. Being recognized as a noble profession, teaching demands meeting high standards through accomplishments of prescribed tasks based on underpinning functions of teachers. It is a "no joke" job as teachers take the responsibility of molding the minds and personality of their students who depend on them for the realization of their dreams whoever they want to be in the future ${ }^{(6)}$. Furthermore, accrediting agencies are demanding proofs of teachers' mastery of their respective subject areas and indication of their professionalism ${ }^{(7)}$. Hence, schools continually monitor and supervise their teachers to ensure consistency of educational tasks with educational goals and meeting the standards. Educational leaders exhaust themselves at trying all approaches they can think of in realizing their targets and encouraging teachers to advance their teaching strategies. Through comparative analysis of the performance of teachers, educational leaders can realize what they need to do to improve the performance of teachers.

Since its breakthrough as a university in 2004, Eastern Samar State University has become the talk of parents for the education of their children. Hence, there was an increase in the number of enrolees and therefore, the number of teachers. The university has gained certain fame among the universities in the region having produced top notchers in national board examinations. This performance in the national examination becomes an inspiration of the top management to aspire for greater heights in the field of education - to produce quality and employable graduates in the local as well as global job markets. Hence, teachers are encouraged to do their best in performing their functions as faculty members of the university. Every semester, each faculty member of the university is subjected to performance review through program heads and deans of each college using the Individual Performance Review form (IPCRF) as outlined in the Joint Resolution of the Congress Number 4 series of 2009. This performance review reflects the three major functions of the faculty members, namely, instruction, research and extension. In the study conducted by Obliopas and Madeja (2020) in the performance of faculty members in research, it indicated that the faculty members are performing low for two years. It is even noted to be waning though it is able to meet the targets ${ }^{(8)}$. Sedanza (2018) stressed that performance of faculty members greatly affects the university's SUC level and accreditation status ${ }^{(9)}$. This is something that needs attention as instruction is supported by research through innovation and extension through delivery packed technologies. Hence, this study is conceptualized to see the performance of faculty members in all the three functions through the comparative analysis of their yearly performance from $2017-2019$.

\section{Objectives}

This study aimed to analyse and determine the performance of faculty members of Eastern Samar State University (ESSU) in the last three years. Specifically the study aimed to achieve the following:

1. Determine the trends in faculty performance based on the following functions:

(a) instruction

(b) research

(c) extension

2. Identify if there is significant difference in faculty performance in the last three years on the following functions:

(a) instruction

(b) research

(c) extension

\section{Hypothesis}

H0: There is no significant difference in faculty performance in instruction, research and extension in the last three years

\section{Methodology}

\section{Research Design}

The design utilized in this study is the retrospective research design. In this design, the outcome of interest has already occurred in each participant by the time he is enrolled in this study, and the data are obtained either from records or by asking subjects 
to recollect exposures. There was no follow-up with the participants or extra data collection that was done ${ }^{(10)}$. Furthermore, an investigator can establish hypothesis about probable correlations between an outcome and exposure to a phenomenon using a retrospective study design. ${ }^{(11)}$. The design was deemed appropriate because the primary goal of the study is to analyze archived records of the performance of the faculty members based on their Individual Performance Commitment Review (IPCR) forms scores for the last three (3) years.

\section{Data Analysis}

The analysis was done in April of academic year 2021 of Eastern Samar State University (ESSU) and covered IPCR scores of faculty members on instruction, research, and extension function from 2017 to 2019 . Accomplished IPCR forms rated by the direct supervisors of each faculty member were obtained from the Human Resource Management Office. A total of eighty four (84) sets IPCR scores were obtained and analyzed. The mean and the standard deviation was computed per indicator in order to interpret the faculty performance per year.

Faculty Performance in Instruction, Research and Extension were interpreted using the Likert scale below

\begin{tabular}{ll}
\hline Likert Scale (Performance in Instruction) & \\
\hline Score & Interpretation \\
\hline $1.00-1.79$ & Poor \\
$1.80-2.59$ & Fair \\
$2.6-3.39$ & Good \\
$3.4-4.19$ & Very Good \\
$4.2-5.0$ & Outstanding \\
\hline
\end{tabular}

\begin{tabular}{ll}
\hline \multicolumn{2}{l}{ Likert Scale (Performance in Research and Extension) } \\
\hline Score & Interpretation \\
\hline $0-0.19$ & Poor \\
$0.2-0.39$ & Fair \\
$0.4-0.59$ & Good \\
$0.6-0.79$ & Very Good \\
$0.8-0.99$ & Outstanding \\
\hline
\end{tabular}

The raw scores were subjected to a normality test to determine the statistical tool that will be used. The Kolmogorov-Smirnov (K-S) normality test revealed that the data for the scores in the instruction indicator is normally distributed, thus the statistical method for the test of difference, analysis of variance (ANOVA), was used ${ }^{(12)}$. The K-S test for the research and extension scores were deemed not normal hence, a non-parametric test specifically the Kruskal-Wallis (H) test was utilized ${ }^{(13)}$.

\section{Results and Discussion}

After a thorough analysis of the IPCR scores of the faculty members, the following results were drawn:

\section{Faculty Performance in Instruction, Research and Extension for the last three years}

As can be gleaned in Table 1, the mean score $(3.62,3.71,3.69)$ for faculty performance in instruction was interpreted to be "very good" from 2017-2019. This result implies that faculty members were consistent in the submission of most of their academic deliverables. This is also evident in the positive variance percentage of $2.47 \%$ (2017-2018). The analysis also resulted to a mean of $0.28,0.32$ and 0.24 for extension for the year 2017-2019 respectively, all of which were interpreted as "fair". This means that the extension performance, although not poor, were below the acceptable threshold which is "good". This further implies that some faculty members failed to regularly conduct some extension activities from 2017-2019 evident in the increase of performance of $14.28 \%$ in $2017-2018$ but a sudden decrease of $25 \%$ from $2018-2019$. Results also revealed that the mean score for research has been consistently tagged as "poor" from 2017-2019, this implies that most faculty members failed to propose, conduct and complete their research projects and was not able to meet their research targets which can also be gleaned in the consistent negative variance percentage for research from 2017-2019. 
Table 1. Comparative analysis of trends in Faculty Performance for the last 3 years

\begin{tabular}{|c|c|c|c|c|c|c|c|c|c|c|c|}
\hline & 2017 & & & & 2018 & & & 2019 & & & \\
\hline & Mean & SD & $\begin{array}{l}\text { Variance } \\
\%\end{array}$ & Interpretation & Mean & SD & $\begin{array}{l}\text { Variance } \\
\%\end{array}$ & InterpretationMean & SD & $\begin{array}{l}\text { Variance } \\
\%\end{array}$ & Interpretatio \\
\hline Instruction & 3.62 & 0.7713 & - & Very Good & 3.71 & 0.8168 & $2.47 \%$ & $\begin{array}{l}\text { Very } \\
\text { Good }\end{array}$ & 0.9181 & $-0.43 \%$ & $\begin{array}{l}\text { Very } \\
\text { Good }\end{array}$ \\
\hline Research & 0.195 & 0.188 & - & Poor & 0.186 & 0.187 & $-4.62 \%$ & 0.162 & 0.176 & $-12.9 \%$ & Poor \\
\hline Extension & 0.28 & 0.147 & - & Fair & 0.32 & 0.164 & $14.28 \%$ & 0.24 & 0.198 & $-25 \%$ & Fair \\
\hline
\end{tabular}

\section{Analysis of Variance for the Instruction function}

Table 2. ANOVA Result for the Instruction Function

\begin{tabular}{|c|c|c|c|}
\hline \multicolumn{4}{|l|}{ INSTRUCTION } \\
\hline & 2017 & 2018 & 2019 \\
\hline $\mathrm{N}$ & 84 & 84 & 84 \\
\hline Mean & 3.62 & 3.71 & 3.69 \\
\hline Std. Dev & 0.7713 & 0.8168 & 0.9181 \\
\hline f-ratio & \multicolumn{3}{|l|}{0.13899} \\
\hline p-value@ 0.05 & \multicolumn{3}{|l|}{0.8704} \\
\hline Interpretation & \multicolumn{3}{|c|}{ Not Significant } \\
\hline
\end{tabular}

The ANOVA result for the Instruction function resulted to a p-value of 0.8704 which is not significant at .05 level of significance. This means that there is no significant difference between the performances of faculty members in instruction from 2017-2019. This further implies that most of the faculty members were able to submit their academic deliverables such as grade sheets, syllabus and TOS on time, and was able to attend relevant trainings and seminars.

Table 3. Kruskal-Wallis Result for the Research Function Scores

\begin{tabular}{ll}
\hline \multicolumn{2}{l}{ RESEARCH } \\
\hline \multicolumn{2}{l}{ Calculation Summary } \\
\hline $\mathrm{N}$ & $84^{*} 3$ \\
$\mathrm{H}$ & $\left(12 /(\mathrm{N}(\mathrm{N}+1))^{*}\left(\sum \mathrm{T} 2 / \mathrm{n}\right)-3(\mathrm{~N}+1)\right.$ \\
$\mathrm{H}$ & $0.001 * 509994.107-381$ \\
$\mathrm{H}-$ Statistic & 1.4478 \\
p-value @ 0.05 & 0.48486 \\
Interpretation & Not Significant \\
\hline
\end{tabular}

The Kruskal-Wallis $(\mathrm{H})$ test resulted to an a p-value of 0.48486 which is not significant at 0.05 level of significance. This implies that there is no discernible difference in faculty members' research performance from 2017 to 2019 . Although the result is not significant, it can be observed that there is a continuous decrease of faculty research performance in table 1.0. This result is in consonance with the research of Madeja and Obliopas (2020) which evaluated the research performance of faculty members of the same institution and discovered that although the targets are consistently being met, there were indicators where there are zero to negative variances, which is indicative of a waning productivity ${ }^{(8)}$.

The Kruskal-Wallis $(\mathrm{H})$ test resulted to a p-value of 0.14412 which is not significant at 0.05 level of significance. This infers that there is no significant difference between the performances of faculty members in extension from 2017-2019. Extension performance of faculty members has also waned by $-31 \%$ in 2019. Sedanza (2018) mentioned that the waning performance of faculty in extension can be attributed to lack of time in conducting extension projects, lack of fund incentives and recognition and ultimately lack of cooperation by the community on the project and other socio-civic activities implemented by the faculty members ${ }^{(9)}$. 
Table 4. Kruskal-Wallis Result for the Extension Function Scores

\begin{tabular}{ll}
\hline \multicolumn{2}{l}{ EXTENSION } \\
\hline \multicolumn{2}{l}{ Calculation Summary } \\
\hline $\mathrm{N}$ & $84^{*} 3$ \\
$\mathrm{H}$ & $\left(12 /(\mathrm{N}(\mathrm{N}+1))^{*}\left(\sum \mathrm{T} 2 / \mathrm{n}\right)-3(\mathrm{~N}+1)\right.$ \\
$\mathrm{H}$ & $0.001^{\star} 513229.726-381$ \\
$\mathrm{H}$ & 3.8742 \\
$\mathrm{p}$-value @ 0.05 & 0.14412 \\
Interpretation & Not Significant \\
\hline
\end{tabular}

\section{Hypothesis Testing}

Since the result of the ANOVA and the Kruskal-Wallis test were resulted to a p-value which are greater than .05 level of significance, we therefore fail to reject the null hypothesis (H0).

\section{Conclusion}

Being part of the university, it is the mandate of each faculty member to perform in instruction, research, extension and production. This research focused on the determination of faculty performance trend in instruction, research and extension in the last 3 years. Based on the analyses made the following conclusions were drawn:

1. The mean scores for faculty performance in instruction was interpreted to be "very good" from 2017-2019. This result implies that faculty members were consistent in the submission of most of their academic deliverables. This is also evident in the positive variance percentage of $2.47 \%$ (2017-2018). Mean scores for Extension were interpreted as "fair". This means that the extension performance, although not poor, were below the acceptable threshold which is "good". This further implies that some faculty members failed to regularly conduct some extension activities from 2017-2019 evident in the increase of performance of $14.28 \%$ in $2017-2018$ but a sudden decrease of $25 \%$ from $2018-2019$. The mean scores for research has been consistently tagged as "poor" from 2017-2019, this implies that most faculty members failed to propose, conduct and complete their research projects and was not able to meet their research targets which can also be gleaned in the consistent negative variance percentage for research from 2017-2019. Negative variances is indicative of a waning productivity which can be attributed to many factors such as lack of time in the conduct of extension and research, lack of funding support and lack of community participation ${ }^{(14)}$. The negative variances in the faculty performance is a manifestation of a serious problem among faculty members in the university but this should serve as a catalyst for the strengthening of faculty performance through the implementation of relevant activities and projects.

2. The same analysis also revealed that there is no significant difference of the faculty performance in instruction ( $\mathrm{p}$-value $=$ $.8704)$, research $(\mathrm{p}$-value $=0.48486)$ and extension $(\mathrm{p}$-value $=0.14412)$ from 2017-2019.

\section{References}

1) Payos RP. Human Resource Management: From Practitioner’s Point of View. Philippines. Rex Book Store, Inc. 2010.

2) Beerens DR. Evaluating Teachers for Professional Growth: Creating a Culture of Motivation and Learning. Thousand Oaks, CA. Sage Publications. 2000.

3) Johansen BCL, Verecio RL, Cinco JC, Quisumbing LA, Laurente ML. Faculty Performance Evaluation in A Philippine University Information Technology Program. .

4) Patimo D. ). Faculty performance evaluation system of state universities and colleges in the philippine eastern visayas region. JISAE: Journal of Indonesian Student Assessment and Evaluation. 2020;6(2):159-167. Available from: https://dx.doi.org/10.21009/jisae.062.06.

5) Warring DF. Teacher Evaluations: Use or Misuse? Universal Journal of Educational Research. 2015;3(10):703-709. Available from: https://dx.doi.org/10. 13189/ujer.2015.031007.

6) Encyclopedia of Education. Supervision of instruction. In Encyclopedia of Education. 2021. Available from: https://www.encyclopedia.com/education/ encyclopedias-almanacs-transcripts-and-maps/supervision-instruction.

7) Lorenz KM. Historical trends and emerging issues in teacher education programs in the United States. 2016. Available from: https://digitalcommons. sacredheart.edu/cgi/viewcontent.cgi?referer=https://www.google.com/\&httpsredir=1\&article=1244\&context=ced_fac.

8) Obliopas RG, Madeja JB. Research policy redirection based on analysis of target- setting and accomplishment trends in a Philippine State University. Indian Journal of Science and Technology. 2020;13(34):3555-3560. Available from: https://dx.doi.org/10.17485/ijst/v13i34.1324.

9) Sedanza NC. Research and Extension Participation, Performance and Motivation of the Leyte Normal University Faculty: Input to Policy Redirection. International Journal of Research -GRANTHAALAYAH. 2018;6(11):184-199. Available from: https://dx.doi.org/10.29121/granthaalayah.v6.i11.2018.1117. 
10) Ranganathan P, Aggarwal R. Study designs: Part 1 - An overview and classification. Perspectives in clinical research. 2018;9(4):184-186. Available from: https://doi.org/10.4103/picr.PICR_124_18.

11) Salkind NJ. Encyclopedia of Research Design. Thousand Oaks, CA. SAGE Publications, Inc.. 2010. doi:10.4135/9781412961288.

12) Sawyer S. Analysis of Variance: The Fundamental Concepts. Journal of Manual \& Manipulative Therapy. 2009;17(2):27E-38E. Available from: https://www.tandfonline.com/doi/abs/10.1179/jmt.2009.17.2.27E.

13) Ghoodjani A. Why should I use a Kruskal Wallis Test?. 2016. Available from: https://www.researchgate.net/publication/305911256_Why_should_I_use_ a_Kruskal_Wallis_Test.

14) Chua C. 2014. Available from: https://citeseerx.ist.psu.edu/viewdoc/download?doi=10.1.1.1021.7326\&rep=rep1\&type=pdf. 